\title{
Miscellany
}

\section{Cash call to keep care advice flowing to former Yugoslavia}

Doctors and other health workers, including nurses, clinical psychologists, dental surgeons, pharmacists and social workers, are being asked to send donations to help provide air fares that will make possible the next stage of visits by volunteer mental health professionals to former Yugoslavia.

The aim is to further MEDACT's work as an 'implementiang partner' in the UNICEF Psychosocial Programme for war-traumatised children. MEDACT is the voluntary association of more than 2000 health professionals in the UK working to prevent war and mitigate its effects and to take action on other issues affecting global health and security.

Cheques, payable to MEDACT, will be welcomed at 601 Holloway Road, London N19 4DL. Further information: Gillian Reeve on 0171281 7434/0171 4853067 (Home).

\section{Psychiatric help for poychiatrists}

We know that psychiatrists may find it difficult for a variety of reasons to get prompt psychiatric help for themselves. Although there are national schemes for 'sick doctors' the Scottish Division believes that a more local and informal scheme might be of more benefit, whereby a distressed psychiatrist can get confidential but appropriately senior expert help.

About a year ago the Scottish Division set up a 'helpline' for psychiatrists working in Scotland. Since then the helpline has been used on several occasions and I would like to remind members that this scheme exists and anyone requiring help can call myself or the Honorary Secretary of the Division (if I am unavailale). I am simply a point of contact and I will arrange for the caller to see a senior psychiatric colleague not working in his or her area, and who will be willing to make a speedy response to the request for help.

Further information: Telephone: 01387 721169; 01387255301 (Dr McCreadie); or 0141 884 5122; 01416441659 (Dr S Whyte).

\section{Scottish Division Annual Award Winners 1995}

The Merck Lipha travel award was won by Dr Gillian Doody; the Dista Audit Award was won by Dr Carol Robertson and the McHarg Essay Prize was awarded jointly to Dr Tom McEwan and Dr Richard Athawes. These papers will be presented at the Scottish Division Summer Meeting in May 1996. Lundbeck Medical Student Prizes were given to Carolyn Orr (Glasgow); Kate Rice and Brian Choo-Kang (both from Edinburgh).

\section{New publications}

A new self-help audio programme, Coping with Stress at Work, from the Defeat Depression Campaign, aims to encourage employees to take the strain out of their stress at work by following a series of effective strategies. This is available for $£ 13.99$ (including p\&p) from Stress Programme, PO Box 1, Wirral LA7 7DD. Further information: 01516320662.

A new National Register, published by Routledge has been published for all those contemplating psychotherapy. It lists all the 3400 qualified UK psychotherapy practitioners, all of whom practice within the guidelines of the United Kingdom for Psychotherapy (UKCP). Further informaion: Jonathan Hearn or Mark Cater, Green Moon Healthcare (Telephone: 0171250 3366).

Unwillingly to School (4th edn) by Ian Berg and Jean Nursten is available from Gaskell/The Royal College of Psychiatrists and priced at $\$ 20.00$. Telephone orders (free p\&p): 01712352351 (ext. 146).

Interpersonal Factors in Origin and Course of Affective Disorders, edited by $\mathrm{Ch}$. Mundt, with the assistance of Hugh Freeman is priced at $£ 25.00$ and is also available from Gaskell/The Royal College of Psychiatrists (ext. 146).

Both the above Gaskell titles may also be purchased from the BMJ Bookshop, Burton Street, London WC1H 9JR (open 9.30 am5.00 pm Monday-Friday). 